\title{
ANALISIS PERLINDUNGAN TERHADAP TOLERANSI KEBEBASAN BERAGAMA DI INDONESIA DALAM PERSPEKTIF HAK ASASI MANUSIA Nathanael Bagas Setyawan* Ridwan Arifin*
}

\begin{abstract}
Activities to religion are generally carried out by all religious communities in the world without limiting an activity in the process, because it can disrupt the worship process. But in its implementation, especially in Indonesia, the public is less aware of the importance of tolerating religious freedom in order to prevent religious conflicts in the concept of Human Rights. Historically, religious problems are a social problem because they involve the lives of people who cannot be separated from the study of social sciences. Therefore, the religious sciences are essentially parts of Sociology, Psychology and Anthropology. Whereas the issue of religious intolerance in Indonesia is a crucial problem, because these problems can divide the Indonesian people, even though religious problems are a problem that does not need to be exaggerated because in essence every religion teaches good things so that the issue of religious freedom of others is in vain. So from that a country needs to have a law to regulate the existing government system, one of which is to regulate religion in Indonesia. Religion in Indonesia itself has been regulated in chapter XI of Religion in Article 29 paragraph (2) where the State guarantees the independence of each resident to embrace their respective religion and to worship according to that belief. Not only about religious freedom, the context of violations concerning religion in Indonesia has also been regulated in law, but the public still underestimates the law because they themselves are also taboo on the laws that apply in Indonesia. Problems concerning religious intolerance can be prevented through counseling on vulnerable areas that will cause religious commotion, so that the pillars of nationality contained in the Pancasila can still survive and run as they should. This study analyzes the Protection of Religious Freedom in Indonesia in the perspective of Human Rights in Indonesia.
\end{abstract}

Kata Kunci :Agama, intoleransi, konflik, kebebasan, perlindungan hukum.

Indonesia adalah sebuah Negara dengan keberagaman suku, agama dan budaya. Sangatlah mungkin jika Indonesia dikatakan menjadi Negara pluralisme. Konsep pluralisme sekenannya menjadi bagian yang penting guna menjalin toleransi antar umat beragama untuk menghilangkan pembatasan-pembatasan yang ada selama ini sering terjadi namun pada kenyataanya batasan-batasan ini masih sangat terasa keberadaannya di negara Indonesia baik dalam lingkungan masyarakat maupun dalam lingkungan dunia kerja yang secara fundamental masih menjunjung tinggi semboyamasih menjunjung tinggi istilah semboyan "Bhinneka Tunggal Ika", yang berarti berbeda-beda tetapi tetap satu jua, yang pada hakikatnya

\begin{tabular}{|c|c|c|c|c|}
\hline $\begin{array}{l}{ }^{*} \text { Fakultas } \\
\text { n.bagassety }\end{array}$ & $\begin{array}{l}\text { Hukum Universitas } \\
\text { vawan@gmail.com. }\end{array}$ & Negeri & Semarang & (UNNES), \\
\hline $\begin{array}{l}{ }^{*} \text { Fakultas } \\
\text { ridwan.arifi }\end{array}$ & $\begin{array}{l}\text { Hukum Universitas } \\
\text { in@mail.unnes.ac.id }\end{array}$ & Negeri & Semarang & (UNNES), \\
\hline
\end{tabular}


istilah itu menjadi semboyan yang sering kita jumpai dan sering kita dengar sehari-hari namun bentuk realita implementasi dari semboyan tersebut masih belum terasa apalagi di zaman sekarang ini. Berikut ini data mengenai persebaran penduduk umat beragama di Indonesia pada tahun 2010 .

\begin{tabular}{|c|c|c|c|c|c|}
\hline \multicolumn{6}{|c|}{ JUMLAH PENDUDUK BERDASARKAN AGAMA DI INDONESIA } \\
\hline \multirow[t]{2}{*}{ PROVINSI } & \multicolumn{5}{|c|}{ AGAMA } \\
\hline & ISLAM & KRISTEN & KATOLIK & HINDU & BUDHA \\
\hline Aceh & 4.413 .244 & 50.309 & 3.315 & 136 & 7.062 \\
\hline Sumatera Utara & 8.579 .830 & 3.509 .700 & 516.037 & 14.644 & 303.548 \\
\hline Sumatera Barat & 4.721 .924 & 69.253 & 40.428 & 234 & 3.419 \\
\hline Riau & 4.872 .873 & 484.895 & 44.183 & 1.076 & 114.332 \\
\hline Jambi & 2.950 .195 & 82.311 & 13.25 & 582 & 30.014 \\
\hline Sumatera Selatan & 7.218 .951 & 72.235 & 42.436 & 39.206 & 59.655 \\
\hline Bengkulu & 1.669 .081 & 28.724 & 6.364 & 3.727 & 2.173 \\
\hline Lampung & 7.264 .783 & 115.255 & 69.014 & 113.512 & 24.122 \\
\hline Kep Bangka Belitung & 1.088 .791 & 22.053 & 14.738 & 1.040 & 51.882 \\
\hline Kep Riau & 1.332 .201 & 187.576 & 38.252 & 1.541 & 111.73 \\
\hline DKI Jakarta & 8.200 .796 & 724.232 & 303.295 & 20.364 & 317.527 \\
\hline Jawa Barat & 41.763 .592 & 779.272 & 250.875 & 19.481 & 93.551 \\
\hline Jawa Tengah & 31.328 .341 & 572.517 & 317.919 & 17.448 & 53.009 \\
\hline D I Yogyakarta & 3.179 .129 & 94.268 & 165.749 & 5.257 & 3.542 \\
\hline Jawa Timur & 36.113 .396 & 638.467 & 234.204 & 112.177 & 60.76 \\
\hline Banten & 10.065 .783 & 268.89 & 115.865 & 8.189 & 131.222 \\
\hline Bali & 520.244 & 64.454 & 31.397 & 3.247 .283 & 21.156 \\
\hline Nusa Tenggara Barat & 4.341 .284 & 13.862 & 8.894 & 118.083 & 14.625 \\
\hline Nusa Tenggara Timur & 423.925 & 1.627 .157 & 2.535 .937 & 5.21 & 318 \\
\hline Kalimantan Barat & 2.603 .318 & 500.254 & 1.008 .368 & 2.708 & 237.741 \\
\hline Kalimantan Tengah & 1.643 .715 & 353.353 & 58.279 & 11.149 & 2.301 \\
\hline Kalimantan Selatan & 3.505 .846 & 47.974 & 16.045 & 16.064 & 11.675 \\
\hline Kalimantan Timur & 3.033 .705 & 337.38 & 138.629 & 7.657 & 16.356 \\
\hline Sulawesi Utara & 701.699 & 1.444 .141 & 99.98 & 13.133 & 3.076 \\
\hline Sulawesi Tengah & 2.047 .959 & 447.475 & 21.638 & 99.579 & 3.951 \\
\hline Sulawesi Selatan & 7.200 .938 & 612.751 & 124.255 & 58.393 & 19.867 \\
\hline Sulawesi Tenggara & 2.126 .126 & 41.131 & 12.88 & 45.441 & 978 \\
\hline Gorontalo & 1.017 .396 & 16.559 & 761 & 3.612 & 934 \\
\hline Sulawesi Barat & 957.735 & 164.667 & 11.871 & 16.042 & 326 \\
\hline Maluku & 776.13 & 634.841 & 103.629 & 5.669 & 259 \\
\hline Maluku Utara & 771.11 & 258.471 & 5.378 & 200 & 90 \\
\hline Papua Barat & 292.026 & 408.841 & 53.463 & 859 & 601 \\
\hline Papua & 450.096 & 1.855 .245 & 500.545 & 2.42 & 1.452 \\
\hline Indonesia & 207.176 .162 & 16.528 .513 & 6.907 .873 & 4.012 .116 & 1.703 .254 \\
\hline
\end{tabular}

Sumber : www.bps.go.id

Sejatinya kebebasan beragama di Indonesia telah dijamin secara konstitusional di dalam Undang-Undang Dasar Negara Republik Indonesia tahun 1945 sebagai bagian dari Hak Asasi Manusia yang mendapat pengakuan, jaminan, dan perlindungan hukum oleh Negara (Radjawene \& Pieter, 2014: 30). Hukum merupakan aturan yang sangat penting dalam sebuah negara guna mengoperasikan sistem-sistem pemerintahan yang sudah ditetapkan. 
Dalam prespektif Hak Asasi Manusia sendiri, setiap orang berhak untuk menentukan sendiri kepercayaannya dan salah satu bentuk manifestasinya ialah dalam hal kebebasan melaksanakan ibadah tanpa mendapatkan intervensi dari pihak manapun. Pada umumnya konflikkonflik beragama timbul karena adanya dominansi antar kaum minoritas dan kaum mayoritas yang mengedepankan ego masing-masing sehingga terjadi gesekan yang lama-kelamaan makin membesar dan terjadilah pertikaian. Perlakuan diskriminatif dan intoleran terhadap kelompok minoritas sampai saat ini juga semakin marak terjadi (Mujtahidin. dkk. 2017: 123). Kelompok minoritas akan kalah jika disandingkan dengan kelompok mayoritas. Ironisnya, kelompok mayoritas menganggap dirinya superior di dalam kehidupan bermasyarakat suatu daerah serta memiliki kuasa terhadap kelompok minoritas. Sedangkan bagi kelompok minoritas kelompok minoritas hanya dapat melakukan berbagai upaya secara rahasia yang dinilai dapat mencapai tujuan kelompoknya. Jika ditelaah lebih dalam, hal inilah yang menjadi penyebab munculnya berbagai aksi-aksi protes.

Disamping itu, hal inilah yang pada akhirnya menyebabkan munculnya berbagai permasalahan serta konflik yang terjadi secara bersiklus karena terjadinya interdominasnsi kaum mayoritas dengan kaum minoritas. Masalah intoleransi agama merupakan masalah krusial yang sejak dahulu telah dihadapi oleh bangsa Indonesia. Berbagai pelanggaran kebebasan beragama marak terjadi hingga saat ini. Sejumlah kasus intoleransi kembali terjadi beberapa hari belakangan. Sejumlah pihak mengecam keras aksi kekerasan agama tersebut, karena dianggap menodai keberagaman dan mencederai wajah demokrasi di Tanah Air. Setara Institute menganggap kasus kekerasan agama ini bagai 'tamparan' bagi tokoh agama dan pemerintah yang baru saja menyelenggarakan Musyawarah Besar Pemuka Agama untuk Kerukunan Bangsa di Jakarta pada 8 hingga 10 Februari 2018. Seperti yang dikatakan Ketua Setara Institut Hendardi pada minggu 12 Februari Ia mengatakan "Setara Institut mengutuk seluruh kebiadaban yang sarat dengan sentimen keagamaan tersebut. Berkaitan dengan itu, kami ingin mengingatksn ulang kepada pemerintah, pemuka agama, dan ekite ormasd-ormas keagamaan bahwa otret riil kerukunan itu terletak di timgkat akar rumput." Dalam perspektif positif, konflik bisa melahirkan ikatan sosial menguat kembali, penegasan identitas yang positif atau kritik terhadap pemahaman keagamaan serta pola pola beragama serta relasi sosial, inspirasi membangun cara terbaik dalam menjalin kemitraan dengan pemeluk agama, dan yang tidak kalah pentingnya sebagai terapi kejut untuk membangun kebersamaan.

Secara umum agama menjadi sumber pokok nilai yang ada dalam kebudayaan. Namun demikian, nilai-nilai tersebut tidak bisa dengan sendirinya mewujud dalam praktek hidup manusia. Dengan kata lain, nilai, gagasan spirit yang diperkenalkan agama, termasuk Islam didalamnya masih bersifat pasif. Tentunya, operasionalisasinya menjadi tugas berat para pemeluknya. Di sinilah salah satu letak masalahnya. Sejauh mana agama bisa membantu proses internalisasi nilai yang dimaksud tersebut. Pada poin ini seperti pandangan Soedjatmoko, harus dibedakan antara kekayaan khasanah, pikiran, dan kaidah-kaidah agama yang ada dalam kitab suci, atau buku agama, dengan kemampuan pemeluknya atau lembaganya untuk memegang peran peradaban, atau pengendali sejarah. 
Pada pandangan teleologis, perbedaan dalam ragam dimensinya, tidak terkecuali perbedaan agama, merupakan suatu keniscayaan, sungguhpun sebagian manusia berupaya menjadikan keanekaragman tersebut menjadi monolitik. Pencipta kehidupan seperti yang dapat dibaca melaluli Kitab-Nya, memberikan ruang kebebasan yang diberikan berkonsekuensi pada adanya tanggung jawab, sehingga secara logis mengharuskan adanya balasan atas pilihan-pilihan hidup.

Pada pandangan sosiologis, manusia dalam hidupnya tidak bisa hidup sendiri. Dibandingkan mahkluk lain, seperti hewan atau tumbuhan, manusia merupakan mahkluk dengan tingkat ketergantungan yang paling tinggi. Maka, komunikasi dengan manusia jelas tidak terhindarkan. Dalam pola dan ragam interaksi muncul konflik sebagai tanggungan perbedaan kebutuhan,perasaan, keinginan, dan harapan lainnya.

Karena manusia sebagai mahkluk sosial. Manusia membutuhkan tidak hanya manusia lain tetapi juga membutuhkan lingkungan sebagai tempat bersosialisasi secara keseluruhan. Dengan demikian, interaksi akan menjadi keniscayaan. Interaksi antar manusia, kelompok tidak pernah steril dari kepentingan, penguasaan, permusuhan, bahkan penindasan.

\section{Pemahaman HAM Sebagai Landasan Kebebasan Beragama}

Hak Asasi Manusia di Indonesia merupakan pemahaman sebagai nilai, konsep dan norma yang hidup dan berkembang di masyarakat yang dapat di telusuri melalui studi terhadap sejarah perkembangan HAM itu sendiri, yang dimulai sejak era pergerakan nasional sampai sekarang. Hal tersebut terjadi karena amandemen terhadap Undang-Undang Dasar (UUD) 1945, yang kemudian amandemen UUD 1945 tersebut secara eksplisit memuat pasal-pasal Hak Asasi Manusia secara lengkap. Seiring berjalannya waktu demokratisiasi, keterbukaan dan perlindungan Hak Asasi Manusia serta upaya mewujudkan negara berdasarkan hukum. Terdapat juga beberapa penyebab-penyebab eksternal tertentu yang turut mempengaruhi perumusan konsep dari norma-norma Hak Asasi Manusia di Indonesia

Secara harifiah yang dimaksud dengan Hak Asasi Manusia adalah hak pokok atau hak dasar (Yudana dalam St. Harum Pujiarto, 1993: 25). Arti harifiah tersebut Hak Asasi merupakan hak yang bersifat fundamental, sehingga keberadaannya merupakan suatu keharusan. Hak asasi manusia juga dimiliki manusia menurut kodratnya, yang tidak dipisahkan dari hakikat dan karena itu bersifat suci (Kuntjoro 1969: 18-19).

Menurut Miriam Budiarjo Hak Asasi Manusia Sebagai hak-hak yang dimiliki manusia diperolehnya dan dibawanya bersamaan dengan kelahiran atau kehadirannya dalam kehidupan bermasyarakat (Miriam Budiardjo, 1981: 120). Karena Hak Asasi merupakan hak yang pokok Hak Asasi Manusia merupakan sesuatu yang dengan sendirinya mengawasi kehidupan manusia dan bukan pemberian dari lingkungan masyarakat. Pernyataan ini sejalan dengan pendapat St. Harum Pujiarto yang menyatakan bahwa Hak Asasi Manusia merupakan sesuatu hak yang awal, bukan sesuatu pemberian dari masyarakat atau negara, hak itu adalah hak hidup dengan segala kebebasannya untuk menyatakan cipta, dan rasa dalam memenuhi hidupnya. Dalam hal ini terdapat Teori Hak Asasi Manusia yang mengatur mengenai yang dapat dilihat dari dua sisi, yaitu teori Universalisme dan Teori Relativisme Budaya (Asmarani, 2015: 32) 
Dari pengertian-pengertian di atas dapat diambil kesimpulan bahwa sejatinya setiap manusia memiliki kebebasan beragama yang absolute secara hak asasi manusia. Namun pada kenyataannya masih banyak pelanggaranpelanggaran kasus kebebasan beragama dan beribadah yang terjadi di Indonesia. Dengan demikian upaya penegakan hukum mengenai kebebasan beragam sangatlah penting dilaksanakan mengingat negara Indonesia adalah negara hukum yang ber ke Bhinekaan

\section{Permasalahan Konflik Beragama di Indonesia}

Indonesia merupakan negara kesatuan yang berke-Bhinekaan yang berarti Indonesia memiliki banyak kebudayaan namun tetap satu jua. Namun pada kenyataannya banyak sekali konflik-konflik beragama yang terjadi di Indonesia, hal tersebut seringkali terjadi di setiap tahun.

Konflik sendiri memiliki arti yang diserap dari bahasa inggris conflict yang berarti percekcokan, perselisihan, pertentangan (Echols dan Hassan Shadily, 1990: 138). Salah satu sumber konflik yang rentan muncul di tengah-tengah masyarakat yang beragam adalah konflik yang bersumber dari perbedaan agama (Rina, 2016:106). Konflik agama selalu berdampak pada aspek lain karena masyarakat dalam melaksanakan kegiatan akan terkotak-kotak dalam kelompok besar sesuai dengan agama yang dianut. Pembangunan dan keamanan tidak dapat dipisahkan fokus perhatiaannya karena dalam rangka melaksanakan pembangunan sangat diperlukan situasi yang aman. Hal ini tentu saja dapat menimbulkan konflik antar umat beragama (Fidiyani, 2016: 501). Oleh karena nya proses terjadinya konflik antar agama perlu diteliti secara cermat dan difahami sehingga dapat dijadikan bahan dalam mengendalikan situasi. Dengan dasar ini maka semua agama yang diakui keberadaannya secara sah dapat melakukan penyebaran.Jaminan konstitusi terhadap hak kebebasan beragama tidak lantas membuat kehidupan antar agama menjadi damai dan rukun. Dengan artian, masih banyak persoalan dan konflik yang terjadi yang dilatarbelakangi oleh perbedaan agama dan perbedaan cara penerimaan serta pemahaman terhadap agama (Jufri, 2016: 41)

Dalam kehidupan masyarakat konflik tidak mungkin sama sekali dapat dihilangkan karena konflik bersifat inheren dalam masyarakat. Oleh karena itu, dalam memelihara ketertiban hanya dapat dilakukan melalui pengelolaan konflik atau dikenal dengan manajemen konflik. Konflik akan terjadi karena adanya sumber penyebab konflik. Pada dasarnya konflik terdiri dari konflik laten atau latent conflict akan berubah menjadi konflik terbuka apabila ada faktor pendorongnya dan sekelompok atau seleruh pihak terkait yang terlibat dalam konflik biasanya kerap kali diwarnai dengan tidnakan-tindakan kekerasan. Pemicu konflik yang dapat datang secara kebetulan saja atau diciptakan untuk kepentingan sepihak sebuah kelompok. Apabila dirasa menguntungkan dengan adanya konflik maka pihak yang menciptakan akan berusaha memelihara kelangsungan konflik. Penyelesaian konflik dapat diwujudkan melalui kesepakatan antar pihak yang sedang berkonflik tanpa ada unsur pemakasaan. Kesepakatan dengan pendekatan kepentingan yang sama akan meredakan situasi konflik secara bertahap.

Dengan adanya konflik pasti akan ada juga pihak yang bekerja untuk membantu masyarakat dalam meredamkan konflik dalam masyarakat seperti TNI-Polri. Namun sebagian masyarakat menilai aparat keamanan 
TNI-Polri yang dikerahkan dalam menangani konflik kurang adil dalam melaksanakan tugasnya, karena berbagai opini bermunculan tentang aparat keamanan yang kurang netral. Bahkan pernah terjadi di indonesia perpecahan anggota Polri menjadi polisi islam dan polisi kristen.

Dewasa ini umat beragama dihadapkan pada tantangan munculnya benturan benturan atau konflik di antara mereka. Konflik yang terjadi pada antar umat beragama semakin memprihatinkan. Konflik merupakan bentuk misinteraktif yang terjadi pada tingkatan individual, interpersonal, kelompok atau pada tingkatan organisasi.Ihsan Ali Fauzi, dalam Aisyah (2014:192)

\section{Upaya Penegakan Kebebasan Beragama}

Hak beragama umumnya sudah terjamin secara konstitusional dalam UUD Tahun 1945, sebagai bagian dari hak asasi manusia yang mendapat pengakuan, jaminan, dan perlindungan hukum oleh Negara sehingga setiap orang berhak untuk bebas dalam menentukan agama dan beribadat menurut agama dan kepercayaan yang dianutnya. Hal ini menimbulkan tanggung jawab dan peran penting dari pemerintah maupun dari masyarakat dalam melakukan tindakan yang sifatnya menghormati setiap orang dalam pengimplementasian hak beragama tersebut.

Hak beragama diakui bagian dari Hak Asasi Manusia, untuk memperkuat hak beragama maka terciptalah undang-undang ke agamaan yang diatur dalam XI Undang-undang dasar 1945 pada pasal 29 yang berbunyi (1) "Negara berdasar atas Ketuhanan Yang Maha Esa". Indonesia sendiri mengakui ada enam agama di Indonesia yaitu Islam, Kristen, Katholik, Hindu, Budha, dan Kong $\mathrm{Hu}$ Chu. Ke enam agama tersebut sejatinya sudah terjamin kemerdekaannya bagi para pemeluk-pemeluknya sesuai dengan pasal 29 ayat (2) yang berbunyi "Negara menjamin kemerdekaan tiap-tiap penduduk untuk memeluk agamanya masing-masing dan untuk beribadat menurut agamanya dan kepercayaannya itu". Dari pasal dan ayat tersebut sejatinya masyrakat tidak perlu resah dan khawatir dalam memeluk sebuah agama karena pemerintah sendiri sudah menjamin akan kemerdekaan beragama dan penjaminan keamanan jika terjadi konflik beragama. Pasal 29 juga dibatasi kewenangannya guna pencegahan tindakan fanatisme berlebihan yang nantinya akan menimbulkan konflik. Pembatasan tersebut tertuang dalam pasal $28 \mathrm{~J}$ ayat 1 yang berbunyi "Setiap orang wajib menghormati hak asasi manusia orang lain dalam tertib kehidupan bermasyarakat, berbangsa, dan bernegara". Sedangkan ayat 2 berbunyi "Dalam menjalankan hak dan kebebasannya, setiap orang wajib tunduk kepada pembatasan yang ditetapkan dengan undang-undang dengan maksud semata-mata untuk menjamin pengakuan serta penghormatan atas hak dan kebebasan orang lain dan untuk memenuhi tuntutan yang adil sesuai dengan pertimbangan moral, nilai-nilai agama, keamanan, dan ketertiban umum dalam suatu masyrkt demokratis.

Situasi untuk melakukan pemajuan hak kebebasan beragama dan berkeyakinan semakin kondusif, akan tetapi di sisi lain masih terdapat fakta bahwa pemenuhan hak atas kebebasan beragama dan berkeyakian di Indonesia merupakan masalah rumit untuk diselesaikan (Agnes Dwi, 2013: 115-122). 


\section{Kesimpulan}

Pada hakikatnya kebebasan beragama merupakan hak yang sudah ada sejak manusia tersebut dilahbilanirkan, karena kebebasan beragama juga merupakan bagian dari hak asasi manusia. Kebebasan beragama secara mutlak juga sudah diatur dalam undang-undang yang disahkan oleh pemerintah. Nilai guna dari undang-undang tersebut adalah untuk menjamin keamanan dan kestabilan ruang lingkup masyarakat mengenai pernasalahan-permasalahan kebebasan beragama. Permasalahan konflik kebebasan beragama timbul karena adanya kaum minoritas dan mayoritas yang melakukan fanatisme secara berlebihan sehingga muncul gesekangesekan antar kaum beragama. Gesekan-gesekan tersebut dapat diminamilisir dengan adanya peraturan yang terdapat di dalam undangundang yang menjamin akan kebebasan beragama. Namun kebebasan tesebut juga harus diatur untuk menjaga stabilita masyarakat agar tidak terjadi hal-hal yang tidak di inginkan seperti terjadinya pemblokadean jalan,pembatasan kehendak beragama orang lain dan lain sebagainya.

Konflik-konflik beragama sebenarnya dapat dihindari dan dapat tidak terjadi apabila masyarakat dapat menghargai satu sama lain akan makna dan arti penting kebebasan beragama tersebut, sehingga tercipta pula kehidupan masyarakat yang harmonis. Dalam hal ini, toleransi agama merupakan sebuah keniscayaan untuk menjamin stabilitas sosial dari paksaan ideologis atau bahkan bentrokan fisik dalam masyarakat. Kehidupan sosial dan agama hendaknya tidak tersisih dari satu sama lain, dan seharusnya terintegerasi kedalam satu sama lain (Casram, 2016: 187). Kondisi konflik beragama dapat semakin parah dan mudah meledak menjadi lebih besar karena tidak ada wadah yang bisa menjembatani antara satu kelompok dengan kelompok lain. Wadah dialog dan wadah komunikasi tidak ada. Namun dengan adanya FKUB (Forum Kerukunan Umat Beragama) dapat digunakan sebagai jembatan atau media dalam upaya merukunkan dan mencegah terjadinya konflik umat beragama.

\section{DAFTAR PUSTAKA}

Agnes Dwi, (2013) "Solidaritas Bagi Kebebasan Beragama", Jurnal Maarif, Vol 5 No.2 Tahun, Jakarta: Maarif Intitute.

Aisyah. (2014). Konflik Sosial dalam Hubungan Antar Umat Beragama. Jurnal Fakultas Dakwah dan Komunikasi UIN Alauddin Makassar, Volume 15, No. 2, 2014.

Arifin, Ridwan. (2018). Penulisan Karya Ilmiah untuk Mahasiswa Hukum. Semarang: BPFH UNNES

Asmarani, Nur. (2015). Teori Hak Asasi Manusia. Jurnal Hukum dan Masyarakat, Volume 14, No. 1, 2015

Budiardjo, Miriam. (1981). Dasar-dasar Ilmu Politik. Jakarta: Gramedia.

Casram. (2016). Membangun Sikap Toleransi Beragama Dalam Masyarakat Plural. Jurnal Ilmiah Agama dan Sosial Budaya, Volume 1, No. 2, 2016.

Echols dan Hassan Shadily (1990), Kamus inggris-Indonesia, Cet XVIII; Jakarta: PT. Gramedia. 
Jufri, Muwaffiq. (2016). Pembatasan Terhadap Hak dan Kebebasan Beragaama di Indonesia. Jurnal Program Studi Ilmu Hukum Universitas Brawijaya, Volume 1, No. 12016.

Kuntjoro Purbopranoto (1969). Hak-HAM dan Pancasila. Jakarta: Pradnya Paramita.

Masmuddin. (2017). Komunikasi Antar Umat Beragama di Kota Palopo (Perspektif Kajian Dakwah). Jurnal IAIN Palopo, Volume 13, No. 1, 2017.

Mujtahidin. dkk.(2017). Peran Nilai Budaya dalam Membentuk Perspektif Toleran dan Intoleran di Madura: Studi kasus Konflik Sunni-Syiah di Desa Karanggayam Kecamatan Omben Kabupaten SampangMadura. Jurnal Universitas Trunojoyo Madura, Volume 10, No. 2, 2017.

Radjawene\& Pieter. (2014). Kebebasan beragama sebagai hak konstitusi di Indonesia. Jurnal Ilmiah Fakultas Hukum Universitas Pattimura Ambon, Volume 20, No. 1, 2014.

Rina, Herawati, dkk.(2016). Toleransi Antar Umat Beragama di Kota Bandung Indonesian Journal of Anthropology, Volume 1, No. 2, 2016.

Rosyid, Moh. (2014). Keselarasan Hidup Beda Agama dan Aliran: Interaksi Nahdliyin, Kristiani, Buddhis, dan Ahmadi di Kudus. Kudus: STAIN Kudus. Jurnal STAIN Kudus, Volume 2, No.1, 2014.

\section{Sumber Online}

www.bps.go.id

Rachmadsyah \& Shantii. (2015). HAM dan Kebebasan Beragma di Indonesia.

Hukum Online. Diakses dari: http://www.hukumonline.com/klinik/detail/cl6556/ham-dankebebasan-beragama-di-indonesia

\section{Peraturan Perundang-undangan}

Undang-Undang Tahun Dasar 1945 BAB XI Pasal 29 ayat 1

Undang-Undang Dasar Tahun 1945 BAB XI Pasal 29 ayat 2

Undang-Undang Dasar Tahun 945 Pasal 28 J ayat 1 dan 2 